\title{
Research on Design Method for Thermal Insulation of Oil Pipeline in Permafrost Regions
}

\author{
WANG Dongyuan ${ }^{1, *}$, ZHAO Zifeng $^{1}$, TAN Qiuxia ${ }^{1}$ and YANG Jian ${ }^{1}$ \\ ${ }^{1}$ China Petroleum Pipeline Engineering Corporation, Langfang, Hebei, 065000, China
}

\begin{abstract}
The most important problems encountered in the design and operation of oil pipelines in permafrost regions are frost heaving and thawing settlement. In this paper, we conducted an investigation and analysis on the status of freezing damage of the operating oil pipelines. Based on the investigation and research, we calculated the temperature field of the oil pipeline and analysed the thawing ability under the conditions of the strain criterion. Finally, we proposed a design method for pipeline insulation and the maximum amount of thawing displacement that the pipeline can withstand. It has certain guiding significance for the thermal insulation design of oil pipelines in permafrost regions.
\end{abstract}

\section{INTRODUCTION}

The most important problems encountered in the design and operation of oil pipelines in permafrost regions are frost heaving and thawing settlement[1-10]. The design and construction of oil pipelines in permafrost regions has its own particularities. The operation of the oil pipeline has a huge impact on the hydrothermal conditions of frozen rock and soil around and along the line[11-25]. The change of the hydrothermal state of frozen and thawed soil directly affects its physical and mechanical characteristics and threatens the overall stability and structural integrity of the pipeline. Due to the differences in geological conditions, the types of frozen soil, and the differences in topography and geomorphology, the freezing and thawing process of the soil around the pipeline has obvious inhomogeneities, which determines the differences in soil frost heave and thawing settlement[26-36]. As a linear project, oil pipelines inevitably have to pass through different freezing and thawing differential deformation transition zones, and the pipes may be damaged due to the excessive frost heave or thawing of the pipeline foundation. Therefore, it is necessary to carry out thermal insulation research on oil pipelines in permafrost regions to guide practical engineering applications.

\section{FROST DAMAGE SURVEY}

At present, the Mo-da Line has officially operated for more than 3 years. According to field investigations and studies, some potential frost damage risks have been discovered, including frost heaving, thawing settlement and adverse frozen ground. The main problem is thawing settlement. During the pipeline design period, the inbound temperature provided by Russia varied from -6 to $10{ }^{\circ} \mathrm{C}$, but the actual operating oil temperature was above the positive temperature. The monitoring results of the oil temperature at each station from 2011 to 2012 show that the oil temperature of the pipeline is above $0{ }^{\circ} \mathrm{Ceven}$ in winter. The average annual oil temperature varies from 4.40 to $9.99^{\circ} \mathrm{C}$, and the extreme oil temperatures during the year are 0.42 and $16.2^{\circ} \mathrm{C}$. During the winter, several frost heaving points were excavated on the site. It was found that a certain range of the perimeter of the pipe was molten soil. The frost heave caused by the soil below the bottom of the pipe has not been found. From the results of oil temperature monitoring, it was found that the pipeline was operating at high temperature and the phenomenon of thawing was obvious. There are different degrees of melting or sinking along the line.

Table 1. Statistics of GPR detection results for typical melting zones

\begin{tabular}{|c|c|c|c|}
\hline \multirow{2}{*}{$\begin{array}{l}\text { Pipeline } \\
\text { mileage }\end{array}$} & \multirow{2}{*}{$\begin{array}{l}\text { Melting } \\
\text { depth in } \\
\text { November } \\
2013(\mathrm{~m})\end{array}$} & \multicolumn{2}{|c|}{$\begin{array}{c}\text { Preliminary calculations } \\
\text { thaw settlement amount }(\mathrm{m})\end{array}$} \\
\hline & & $\begin{array}{l}\text { thawing } \\
\text { settlement }\end{array}$ & $\begin{array}{l}\text { strong thawi } \\
\text { ng settlement }\end{array}$ \\
\hline $\mathrm{mdx} 40$ & 2.5 & \multirow{2}{*}{$0.08 \sim 0.25$} & \multirow{2}{*}{$0.25 \sim 0.63$} \\
\hline $\mathrm{mdx} 113$ & 2.5 & & \\
\hline $\mathrm{mdx} 285$ & 4.5 & $0.13 \sim 0.45$ & $0.45 \sim 1.13$ \\
\hline mdx304 & 3.0 & $0.09 \sim 0.3$ & $0.3 \sim 0.75$ \\
\hline mdx364 & 3.5 & \multirow{2}{*}{$0.11 \sim 0.35$} & \multirow{2}{*}{$0.35 \sim 0.88$} \\
\hline mdx391 & 3.5 & & \\
\hline
\end{tabular}

According to the thawing depth monitoring data (Table 1), it is possible to calculate the thawing amount corresponding to different thawing levels (about 0.45 to $1.1 \mathrm{~m}$ ), which is basically consistent with the site thawing monitoring data $(0.5$ to $0.88 \mathrm{~m})$. It can be known that the types of frozen soils in areas where the amount of thawing is obvious are generally thawing $\sim$ strong thawing ice-rich $\sim$ saturated frozen soil.

\footnotetext{
* Corresponding author: cppewangdy@ cnpc.com.cn
} 


\section{CALCULATION MODEL OF PIPELINE TEMPERATURE FIELD}

There may be different amounts of water (ice) frozen soil in various places along the pipeline, there may be frost-heavy soil layers. Therefore, the prediction and analysis of the freeze-thaw cycle in typical regions select clay that is not conducive to pipeline stability. The material parameters of the model vary according to the stratum profile and different water content (ice) content, and are selected from the original test data, as shown in Table 2.

Table 2. Thermophysical parameters of each soil layer

\begin{tabular}{|c|c|c|c|c|}
\hline \multirow{2}{*}{$\begin{array}{c}\text { Geotechnical } \\
\text { properties }\end{array}$} & \multicolumn{2}{|c|}{$\begin{array}{c}\text { Thermal Conductivity } \\
\left(\mathrm{w} / \mathrm{m} \cdot{ }^{\circ} \mathrm{C}\right)\end{array}$} & \multicolumn{2}{c|}{$\begin{array}{c}\text { Specific heat } \\
\left(\mathrm{J} / \mathrm{kg} \cdot{ }^{\circ} \mathrm{C}\right)\end{array}$} \\
\cline { 2 - 5 } & $\begin{array}{c}\text { Frozen } \\
\text { soil }\end{array}$ & $\begin{array}{c}\text { Thawing } \\
\text { soil }\end{array}$ & $\begin{array}{c}\text { Frozen } \\
\text { soil }\end{array}$ & $\begin{array}{c}\text { Thawi } \\
\text { ng soil }\end{array}$ \\
\hline Subsoil & 1.82 & 1.6 & 982 & 1273 \\
\hline Silty clay & 2.12 & 1.42 & 1222 & 1608 \\
\hline $\begin{array}{c}\text { Fully } \\
\text { weathered } \\
\text { sandstone }\end{array}$ & 1.82 & 1.6 & 982 & 1273 \\
\hline
\end{tabular}

In this study, polyurethane foam was used as the thermal insulation material, and the thermal conductivity was about $0.03 \mathrm{~W} /(\mathrm{m} \cdot \mathrm{K})$. Based on this model, the development of the melting circle and the melting depth of the bottom of the pipeline under the conditions of different parallel spacing and with or without thermal insulation layer, and the soil around the pipeline under different frozen soil types are studied. It can be concluded that there are important reference values for the design of Moda second-line crude oil pipeline.

\subsection{Without thermal insulation}

The calculation and analysis are performed for six pitch schemes of $6 \mathrm{~m}, 8 \mathrm{~m}, 10 \mathrm{~m}, 12 \mathrm{~m}, 30 \mathrm{~m}$, and $50 \mathrm{~m}$, and the parallel spacing of the two pipes without thermal influence on each other are obtained when the insulation is not maintained.

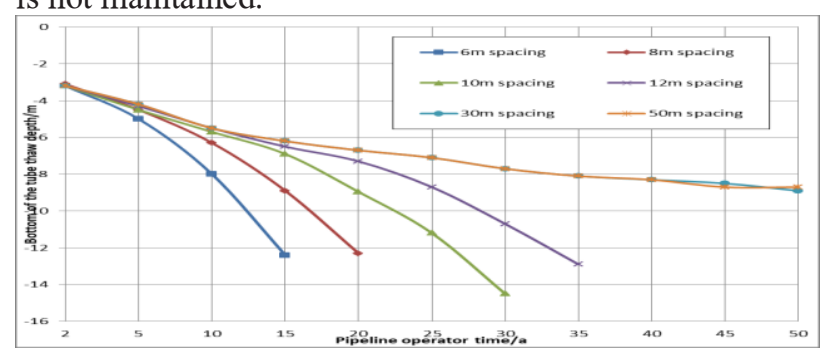

Fig. 1.The process of melting depth of tube bottoms with different parallel spacings as a function of operating time

Through the study of the parallel spacing (Figure 1), it can be concluded that if the double pipes are parallel without any insulation measures, the parallel spacing needs to be at least $30 \sim 50 \mathrm{~m}$ to avoid the superimposed effect of the double pipes on the thermal effects of frozen soil at the bottom of the pipes. Since this distance is unlikely to be achieved, it is recommended that necessary insulation measures be taken to reduce the parallel spacing.

\subsection{Thermal insulation of pipelines}

Considering the Greater Xing'an Mountains forest area, in order to reduce felling and land occupation, the parallel distance should be reduced, and to reduce the thermal impact of double pipes on the frozen soil around the pipe, consider the temperature of the second line when the double pipe is $8 \mathrm{~m}$ Calculate and analyze the temperature field calculation of the different insulation schemes of the two pipes. The calculation results are shown in Table 3.

Table 3. Statistics of tube bottom melting depth under different insulation schemes

\begin{tabular}{|c|c|c|c|c|}
\hline \multirow{2}{*}{$\begin{array}{c}\text { Insulation } \\
\text { scheme }\end{array}$} & Insulation type & $\begin{array}{c}\text { 2nd } \\
\text { year } \\
\text { thaw } \\
\text { depth } \\
/ \mathrm{m}\end{array}$ & $\begin{array}{c}\text { 30thyear } \\
\text { thaw } \\
\text { depth } / \mathrm{m}\end{array}$ & $\begin{array}{c}50 \text { th } \\
\text { year } \\
\text { thaw } \\
\text { depth } \\
\text { /m }\end{array}$ \\
\hline \multirow{2}{*}{ I } & $\begin{array}{c}\text { First line } \\
\text { uninsulated }\end{array}$ & 2.2 & 6.1 & 7.5 \\
\cline { 2 - 5 } & $\begin{array}{c}\text { Second-line } \\
\text { insulation }\end{array}$ & 0.3 & 1.9 & 2.6 \\
\hline \multirow{3}{*}{ II } & $\begin{array}{c}\text { First line } \\
\text { insulated }\end{array}$ & 0.3 & 1.7 & 2.3 \\
\cline { 2 - 5 } & $\begin{array}{c}\text { Second- } \\
\text { lineuninsulation }\end{array}$ & 2.2 & 6.3 & 7.5 \\
\hline \multirow{3}{*}{ III } & $\begin{array}{c}\text { First line } \\
\text { insulated }\end{array}$ & 0.4 & 0.9 & 0.9 \\
\cline { 2 - 5 } & $\begin{array}{c}\text { Second-line } \\
\text { insulation }\end{array}$ & 0.3 & 1.0 & 1.0 \\
\hline
\end{tabular}

Using this model, the temperature field of the pipeline under future heating conditions was calculated (Figure 2). It can be seen from the figure that after the oil temperature increases, when the pipe is provided with a thermal insulation layer, the maximum melting depth is increased from $2.0 \mathrm{~m}$ to $9 \mathrm{~m}$.

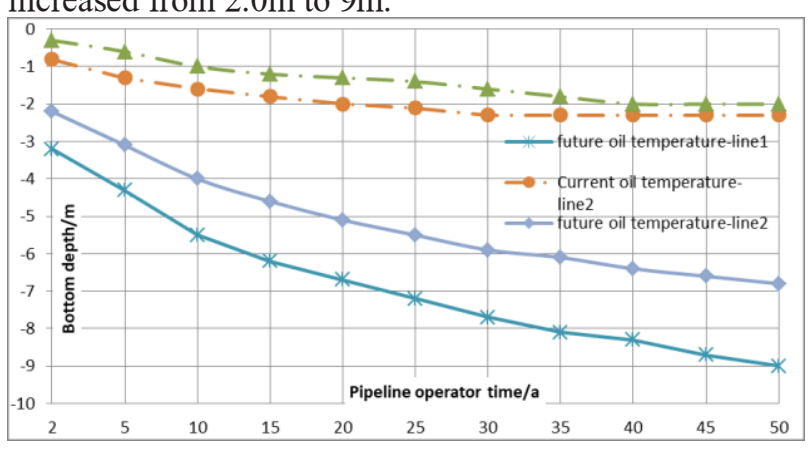

Fig. 2. Melting depth curve of tube bottom in frozen soil area under new and old oil temperature

\subsection{Analysis of Deformation Capability}

From the summary table of the stress and strain calculation of the pipeline under different thawing displacements (Table 4), it can be seen that regardless of the type of frozen soil, as the soil displacement increases, the stress and strain value of the pipeline is also Increase accordingly. The pipeline safety check was performed 
according to the strain criterion. The maximum axial compressive strain and maximum tensile strain of the pipeline were within the allowable range (the maximum allowable compressive strain was $0.77 \%$ and the maximum allowable tensile strain was $1 \%$ ). The pipeline strain check passed.

Table 4. Summary table of pipeline stress and strain calculation under different thawing displacements

\begin{tabular}{|c|c|c|c|c|}
\hline $\begin{array}{c}\text { Pipeline } \\
\text { settleme } \\
\mathrm{nt} / \mathrm{m}\end{array}$ & $\begin{array}{c}\text { Effectiv } \\
\text { e stress } \\
/ \mathrm{MPa}\end{array}$ & $\begin{array}{c}\text { Equivale } \\
\text { nt stress } \\
/ \mathrm{MPa}\end{array}$ & $\begin{array}{c}\text { Maximum } \\
\text { compressi } \\
\text { ve strain }\end{array}$ & $\begin{array}{c}\text { Maximu } \\
\mathrm{m} \text { tensile } \\
\text { strain }\end{array}$ \\
\hline 0.77 & 451 & 519 & $0.31 \%$ & $0.17 \%$ \\
\hline 0.89 & 453 & 521 & $0.39 \%$ & $0.20 \%$ \\
\hline 1.45 & 452 & 520 & $0.37 \%$ & $0.20 \%$ \\
\hline 1.65 & 453 & 521 & $0.41 \%$ & $0.21 \%$ \\
\hline
\end{tabular}

The results of multiple trial calculations are shown in Figure 3 below. From the table, it can be concluded that under the condition of $16 \mathrm{~mm}$ wall thickness, the maximu $\mathrm{m}$ thawing displacement $\Delta \mathrm{S}$ that the pipeline can withsta nd is in the range of $2.0 \mathrm{~m} \sim 2.2 \mathrm{~m}$.

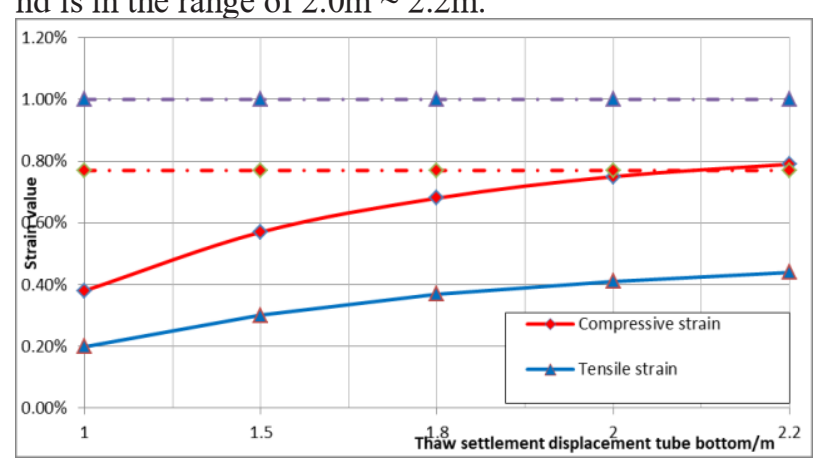

Fig. 3.Strain change trend of D813 pipeline under different thawing displacements (under the condition of strain criterion)

\section{CONCLUSIONS}

In this paper, through research on the thermal insulation design method of oil pipelines in permafrost regions, we can draw many conclusions that have important reference value for pipeline design in permafrost regions. The main conclusions are as follows:

(1) The thermal effects of uninsulated pipes on frozen soil are very strong. The melting depth exceeds $7 \mathrm{~m}$, and the thaw is large $(1.7 \mathrm{~m})$. On the one hand, the deformation of the pipeline is exacerbated, and on the other hand, the geomorphology and ecology are greatly destroyed. Considering the irreversibility of the frozen soil ecological environment, it is recommended that oil pipelines be considered for additional insulation.

(2) When the oil pipeline is added with an insulation layer, the melting depth is stable after 15 years, the maximum melting depth is controlled within $1 \mathrm{~m}$, and the thawing amount is only $0.2 \mathrm{~m}$.
(3) Under the condition of $16 \mathrm{~mm}$ wall thickness, the maximum thawing displacement $\Delta \mathrm{S}$ that the pipeline can withstand is in the range of $2.0 \mathrm{~m} \sim 2.2 \mathrm{~m}$.

\section{Acknowledgment}

Thanks to the researchers from Cold and Arid Regions Environmental and Engineering Research Institute, Chinese Academy of Sciences (CAREERI, CAS) for their help in the research process, and also to everyone in the research team.

\section{References}

1. Copons R, Vilaplana J. Rockfall susceptibility zoning at a large scale From geomorphological inventory to preliminary land use planning[J]. Engineering Geology.2008,102:142-151.

2. Luuk.K.A, Dorren. Mechanisms, effects and management implications of rock fall in forests[J]. Forest Ecology and Management, 2005(215):183-19.

3. S.K.Datta, etc. Dynamic response of pipelines to moving loads[A]. Proe.8th WCEE, 1984.

4. Ying-Xiang WU, Non-linear wave-induced transient response of soil around a trenched pipeline[J].Ocean Engineering, 2006(33): 311-330.

5. P.Ruta, A.SZydlo. Drop-weight test based identification of elastic half-space model Parameters[J]. Journal of Sound and Vibration, 2005(282): 411-427.

6. Labiouse V, Descoeudres F, Montani S. Experimental study of rock sheds impacted by rock blocks [J]. Struct Eng Int, 1996,3(1):171-175.

7. B.Piehler, Ch.Hellmieh, H.A.Mang. Impact of rocks onto gravel Design and evaluation of experiments[J]. International Journal of impact Engineering, 2005(31):559-578.

8. White.H.L. Largest Metal Culvert Designed by Ring Compression Theory [J]. Civil Eng, 1961,52-55.

9. Newmark.N.M, Hall.W.J. Pipeline design to resist large fault displacement[A], Earthquake Engineering Resinst, 1975: 416-425.

10. K.T.Chaua, R.H.C.Wonga, J.J. Wu. Coefficient of restitution and rotational motions of rockfall impacts [J]. International Journal of Rock Meehanies \& Mining Sciences, 2002.39(69):69-77.

11. Labiouse V, Heidenreieh B. Half-scale experimental study of rockfall impacts on sandy slopes [J]. Natural Hazards and Earth System Scienees.2009(9): 1981-1993.

12. Parmelee.R.A, Ludtke.C.A. Seismic soil-structure inter action of buried pipelines[A].Welding of pipelines and related facilities[S].Washington DC, USA,2005.

13. G.E.Muleski, T.Ariman, C.P Aumen .A shell model of a buried pipe in seimic enviriment[J].Pressure Vessel Technology, 1979(101):44-55. 
14. A.Hindy, M.Novak. Earthquake response of underground pipelines[J]. Earthquake Engineering and Structural Dynamics,1979(17):451-476.

15. Dorren L. A review of rockfall mechanics and modelling approaches[J]. Progress in Physical Geography. 2003, 27(1): 69-87.

16. Bozzolo D, Pamini B. Simulation of Rock Falls down a valley side[J]. ACTH Mechanica.1986, 63: 113-130.

17. Schneuwly D, Stoffel M. Spatial analysis of rockfall activity bounce heights and geomorphic changes over the last 50 years-A case study using dendrogeomorphology[J]. Geomorphology. 2008, 102: 522-531.

18. A.Azzoni. Analysis and Prediction of Rockfalls Using a Mathematical Model [J].Elsevier Science, 1995,32(7):709-724.

19. ZHONG W, GAO J F. Hazard assessment of typical geological disasters along oil and gas pipeline[J]. Oil \& Gas Storage and Transportation, 2015, 34(9): 934-938.

20. SHI X W, DENG Q L, DONG G L. The hazards of landslides and rockslides to pipeline[J]. Oil \& Gas Storage and Transportation, 2013, 32(3): 295-299.

21. YANG J R, BAI Y, YANG X D, et al. Numerical simulation and tests for flexible rock shed subjected to rackfall impact[J]. Journal of Vibration and Shock, 2017, 36(9): 172-178, 246.

22. ZHOU Y H. Combined Application of Flexible Support Network for Prevention of Rockfall along Side Slope and Unstable Rock[J].Subgrade Engineering, 2017, (5): 157-163.

23. YANG Z Q, CHEN D X, GAO Q, et al. Key technologies in long-distance pipeline transportation of filling slurry of coarse aggregate[J]. Journal Of Guangxi University (Natural Science Edition), 2016, 41(4): 1306-1312.

24. LIU Y Y, ZHOU G Q, SU Y H, etal. Experimental study of swell-shrinking characteristics of the mixture of eps granules and expansive soil[J]. Industrial Construction, 2017, 47(5): 90-95.

25. WANG X M, GU A Q. Anti-loading measures for vertical earth pressure of buried pipeline[J]. Chinese Jounal Of Geotechnical Engineering, 1990, 12(3): 83-89.

26. Zarnani S, Bathurst R J. Numerical parametric study of expanded polystyrene (EPS) geofoam seismic buffers [J]. Canadian Geotechnical Journa1, 2009, 46(3): 318-338.

27. BAI B, LU S Q. Test of Styrofoam and Its Application in Geotechnical Engineering [J]. Chinese Jounal Of Geotechnical Engineering, 1993, 15(2): 104-108.

28. GU A Q, GUO T T, WANG X P. Experimental study on reducing-load measurement using EPS of culvert under high-stacked soil[J]. Chinese Journal Of Geotechnical Engineering, 2005, 27(5): 500-504.
29. Wang Z L, Li Y C, Wang J G. Numerical analysis of attenuation effect of EPS geofoam on stresswaves in civil defense engineering $[\mathrm{J}]$. Geotextiles and Geomembranes, 2006, 24: 265-273.

30. A.Ossa, M.P.Romo.Dynamic characterization of EPS geofoam[J]. Geotextiles and Geomembranes, 2010, 29 (2011): 40-50.

31. CAO Q K, XIE R, SHEN H M. Seismic Response Analysis of High-Rise EPS Lattice Type Concrete Wall[J]. Earthquake Resistant Engineeringand Retrofitting, 2017, 39(5): 18-25,33.

32. JIA P, XU Y F. The Review of the Strength and Deformation Characteristics of the EPS Block[J]. Modern Transportation Technology, 2017, (6): 8-11.

33. GU A Q, LV Z F, JIANG F L, et al. Load reduction tests and design methods for culverts with high fill soil using eps slabs[J]. Chinese Journal Of Geotechnical Engineering, 2009, 31(10): 1481-1486.

34. Krieg R D. A simple constitutive description for soils and crushablefoam SCDR-72-0883[R]. Albuquerque: Sandia National Laboratories, 1972, 122-123.

35. Zhang J, Kikucbi N, Li V, et al. Constitutive modeling of polymericfoam material subjected to dynamic crash loading[J]. International Journal of lmpact Engineering, 1998, 21 (5): 369-386.

36. Livermore Software Technology Corporation (LSTC). LS-DYNA Keyword user'sManual [M]. California: Computer technology press, 2003:98139. 